\title{
PENGARUH KOMPETENSI DAN INDEPENDENSI AUDITOR TERHADAP KUALITAS AUDIT PADA KANTOR AKUNTAN PUBLIK DI MAKASSAR
}

\author{
Ade Damayanty Vina Giovani ${ }^{1}$, Dini Rosyada ${ }^{1}$ \\ ${ }^{1}$ Jurusan Akuntansi, Sekolah Tinggi Ilmu Ekonomi Panca Bhakti Palu \\ adegeo0585@gmail.com \\ dinirosy@gmail.com
}

\begin{abstract}
This study aims to examine and analyze the influence of competencies and independence on audit quality in Public Accountant Office in Makassar. A questionnaire was distributed to the auditors totaling 50 auditors in seven public accountant offices. The analytical method used is multiple regression analysis. The results of the study show that auditor competency has a positive and significant effect on audit quality. Auditor independence also has a significant effect on audit quality. This results reveal that auditor competency and independency can improve audit quality.
\end{abstract}

Keywords: Competence; Independence; Audit Quality

\section{ABSTRAK}

Penelitian ini bertujuan untuk menguji dan menganalisis pengaruh kompetensi dan independensi terhadap kualitas audit pada Kantor Akuntan Publik di Makassar. Kuesioner yang disebar ke 50 auditor di tujuh Kantor Akuntan Publik. Metode analisis yang digunakan adalah regresi linier berganda. Hasil penelitian ini menunjukkan bahwa kompetensi auditor memiliki pengaruh positif dan signifikan terhadap kualitas audit. Independensi auditor juga memiliki pengaruh signifikan terhadap kualitas audit. Hasil ini mengungkap bahwa kompetensi dan independensi auditor dapat meningkatkan kualitas audit.

Kata Kunci : Kompetensi; Independensi; Kualitas Audit

Jurnal Akun Nabelo: Jurnal Akuntansi Netral, Akuntabel, Objektif

Volume 2/Nomor 1/Juli 2019 Jurusan Akuntansi FEB-Universitas Tadulako

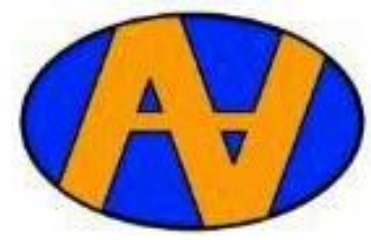




\section{A. PENDAHULUAN}

Kebutuhan jasa profesional akuntan publik akhir-akhir ini semakin meluas. Akuntan publik harus dapat meningkatkan kinerjanya agar menghasilkan kualitas audit yang dapat diandalkan bagi pihak yang mem-butuhkan. Untuk meningkatkan sikap profesionalismenya sebagai akuntan publik maka dalam melaksanakan tugas auditnya, auditor harus berpedoman pada Standar Auditing yang telah ditetapkan dan disahkan oleh Institut Akuntan Publik Indonesia (IAPI), yakni standar umum, standar pekerjaan lapangan dan standar pelaporan, serta mentaati Kode Etik Akuntan Indonesia.

Kualitas jasa audit ditentukan oleh dua hal yaitu kompetensi dan indepedensi (Christiawan, 2002), Kompetensi berkaitan dengan kemampuan, keahlian dan pengalaman dari auditor (Christiawan, 2002). Dalam melaksanakan audit, akuntan publik harus bertindak sebagai seorang yang ahli dalam bidang akuntansi dan auditing. Pencapaian keahlian sebagai auditor, seseorang harus telah memperoleh pendidikan formal, pelatihan teknis yang kemudian diperluas melalui pengalaman dalam praktik audit. Pengalaman merupakan unsur profesi terpenting karena akan mempengaruhi kemampuan auditor untuk mengetahui kekeliruan dan pelatihan yang dilakukan akan meningkatkan keahlian dalam melakukan audit. Sedangkan independensi adalah sikap auditor yang jujur, tidak memihak, dan tidak mudah dipengaruhi (Christiawan, 2002).

Untuk menghasilkan kualitas audit yang tinggi, maka banyak faktor yang perlu diperhatikan, namun dalam penelitian ini auditor hanya memerlukan dua hal utama, yaitu kompetensi dan independensi. Menurut Christiawan (2002) kompetensi berkaitan dengan pendidikan dan pengalaman memadai yang dimiliki akuntan publik dalam bidang auditing dan akuntansi. Sedangkan menurut Alim, et.al. (2007), kompetensi merupakan pengetahuan, ketrampilan, dan kemampuan yang berhubungan dengan pekerjaan, serta kemampuan yang dibutuhkan untuk pekerjaan-pekerjaan non-rutin.

Seorang auditor internal dalam melakukan audit harus memiliki kompetensi melalui pengetahuan tentang audit, pengalaman yang cukup serta mengikuti pelatihan teknik yang cukup, karena hal itu merupakan syarat dari standar umum audit. Sebagaimana SA Seksi 210 dalam SPAP 2009 menyebut-kan bahwa audit harus dilaksanakan oleh seorang atau lebih yang memiliki keahlian dan pelatihan teknis yang cukup sebagai auditor, sedangkan standar umum ketiga menyebutkan bahwa dalam pelaksanaan audit dan penyusunan laporannya, auditor wajib menggunakan kemahiran profesionalnya dengan cermat dan seksama.

Selain kompetensi, maka inde-pendensi berpengaruh terhadap kualitas audit, dimana menurut standar Auditing Seksi 220.1 (SPAP : 2009) menyebutkan bahwa independen bagi seorang auditor internal tidak mudah dipengaruhi karena audit internal melaksanakan pekerjaan-nya untuk kepentingan umum. Oleh karena itu auditor internal tidak dibenarkan memihak kepada siapapun, sebab bagaimanapun sempurnanya keahlian teknis yang dimilikinya, ia akan kehilangan sikap tidak memihak yang justru sangat diperlukan untuk memper-tahankan kebebasan pendapatnya. Oleh karena itu, dalam memberikan pendapat mengenai kewajaran laporan keuangan yang diperiksa seorang auditor internal harus bersikap independen terhadap kepentingan klien, para pemakai laporan keuangan, maupun terhadap laporan keuangan perusahaan yang diaudit. Alim, et.al. (2007) menyatakan bahwaindependensi seorang auditor di-pengaruhi oleh ukuran perusahaan klien dan pemberian hadiah. Banyaknya penelitian mengenai independensi menunjukkan bahwa faktor independensi merupakan faktor yang penting bagi seorang auditor dalam menjalankan profesinya.

Para pengguna laporan keuangan akan lebih mempercayai informasi dalam laporan keuangan yang telah dibuat oleh agen setelah laporan tersebut diperiksa kebenarannya oleh auditor. Untuk itu, auditor harus memiliki 
kredibilitas dalam melakukan pekerja-annya sehingga auditor dapat menghasilkan laporan audit yang berkualitas.

Penelitian ini dilakukan pada kantor Akuntan Publik di kota Makassar, dimana fenomena yang terjadi pada perusahaan perbankan bahwa kualitas audit yang dilakukan oleh auditor internal belum sesuai dengan standar auditing yang lazim berlaku, hal ini disebabkan karena kurangnya kompe-tensi melalui pengetahuan, keahlian dan pengalaman yang dimiliki oleh auditor internal, selain dalam memberikan pendapat mengenai kewajaran laporan keuangan yang diperiksa harus bersikap independen terhadap kepentingan klien, para pemakai laporan keuangan, maupun terhadap kepentingan akuntan publik itu sendiri.

Berdasarkan latar belakang masalah dalam penelitian ini maka yang menjadi rumusan masalah dalam penelitian ini, yaitu:

1. Apakah kompetensi berpengaruh terhadap kualitas audit pada Kantor Akuntan Publik di Makassar.

2. Apakah independensi berpengaruh terhadap kualitas audit pada Kantor Akuntan Publik di Makassar.

3. Variabel manakah yang dominan berpengaruh terhadap kualitas audit pada Kantor Akuntan Publik di Makassar.

\section{B. LANDASAN TEORI}

\section{B.1. Teori Atribusi}

Atribusi adalah sebuah teori yang membahas tentang upaya-upaya yang dilakukan untuk memahami penyebab-penyebab perilaku kita dan orang lain. Definisi formalnya, atribusi berarti upaya untuk memahami penyebab di balik perilaku orang lain, dan dalam beberapa kasus juga penyebab di balik perilaku kita sendiri.

Seperti telah disebutkan diatas bahwa teori ini menjelaskan tentang sebabsebab perilaku manusia. Apakah perilaku itu disebabkan oleh faktir dalam, yang merupakan disposisi internal, missal sikap, sifat-sifat tertentu atau aspek internal yang lain, ataukah oleh keadaan eksternal, missal situasi. Teori ini dikemukakan oleh Fritz Heider (dalam Baron dan Byrne, 1984), yang mana pada dasarnya perilaku manusia itu dapat atribusi internal, akan tetapi juga dapat atribusi eksternal (Walgito, 2001).

\section{B.2. Pengertian Audit}

Audit bagi perusahaan merupakan hal yang cukup penting karena memberikan pengaruh besar dalam kegiatan perusahaan yang bersangkutan. Pada awal perkembangannya auditing hanya dimaksudkan untuk mencari dan menemukan kecurangan serta kesalahan, kemudian berkembang menjadi peme-riksaan laporan keuangan untuk memberikan pendapat atas kebenaran penyajian laporan keuangan perusahaan dan juga menjadi salah satu faktor dalam pengambilan keputusan.

Pengertian audit menurut Simamora (2011: 4) adalah suatu proses sistematik pencarian dan pengevaluasian secara obyektif bukti mengenai asersi tentang peristiwa dan tindakan ekonomik untuk meningkatkan kadar kesesuaian antara asersi tersebut dengan kriteria yang ditetapkan, dan mengkomuni-kasikan hasilnya kepada pemakai yang berkepentingan.

Kemudian pengertian audit menurut Mulyadi (2008: 9) adalah proses sistematik untuk memperoleh dan mengevaluasi bukti secara objektif mengenai pernyataan-pernyataan tentang kegiatan dan kejadian ekonomi, dengan tujuan untuk menetapkan tingkat kesesuaian antara pernyataan-pernyataan tersebut dengan kriteria yang ditetapkan, serta menyampaikan hasil-hasilnya kepada pemakai yang berkepentingan.

\section{B.3 Laporan Audit}

Laporan audit merupakan satu-satunya dari produk unit audit internal yang secara teratur dilaporkan kepada manajemen senior, dewan direksi, dewan komisaris, dan komite audit. Karena merupakan satu-satunya produk audit yang sampai kepada mereka, pembaca cenderung mengasosiasikan kualitas laporan dengan kinerja dan kemampuan profesional unit audit internal. 
Sebagai profesi yang sudah mapan, auditor internal memiliki Standar Profesi Audit Internal sebagai suatu sistem untuk menjamin diterbitkannya laporan audit internal yang berkualitas. Menurut Tugiman (2008: 70), laporan audit haruslah objektif, jelas, singkat, konstruktif dan tepat waktu.

Laporan tersebut merupakan alat tugas dan wewenang bagiannya. Laporan audit menurut Sawyer (2006: 11) adalah laporan audit termasuk ringkasan eksekutif, dirancang untuk mengkomuni-kasikanperbaikan-perbaikan yang disarankan dan rencana-rencana manajemen operasional untuk melaksanakan perbaikan tersebut.

\section{B.4. Kompetensi}

Lee dan Stone (1995) dalam Irawati (2011) mendefinisikan kompe-tensi sebagai suatu keahlianyang cukup secara eksplisit dapat digunakan untuk melakukan audit secaraobyektif. Pendapat lain adalah dari Dreyfus dan Dreyfus (dalam Saifudin, 2004),mendefinisikan kompetensi sebagai keahlian seorang yang berperan secaraberkelanjutan yang mana pergerakannya melalui proses pembelajaran, dari "pengetahuan sesuatu" ke "mengetahui bagaimana", seperti misalnya dari sekedar pengetahuan yang tergantung pada aturan tertentu kepada suatupertanyaan yang bersifat intuitif.

Definisi keahlian dalam bidang auditing pun sering diukur dengan pengalaman (Mayangsari, 2003). Pengetian keahlian menurut Bedard (1986) dalam Murtanto (1999) adalah seseorang yang memiliki pengetahuan dan keterampilan prosedural yang luas yang ditunjukkan dalam pengalaman audit.

Berdasarkan uraian di atas dapat ditarik kesimpulan bahwa kompetensi auditor adalah auditor yang dengan pengetahuan dan pengalaman yang cukup dan eksplisit dapat melakukan audit secara objektif, cermat dan seksama.

\section{B.5 Pengalaman}

Audit menuntut keahlian dan profesionalisme yang tinggi. Keahlian tersebut tidak hanya dipengaruhi oleh pendidikan formaltetapi banyak faktor lain yang mempengaruhi antara lain adalahpengalaman. Menurut Tubbs (1992) dalam Mayangsari (2003) auditor yang berpengalaman memiliki keunggulan dalam hal: (1) mendeteksi kesalahan, (2) memahami kesalahan secara akurat, dan (3) mencari penyebab kesalahan. Libby dan Frederick (1990) dalam Kusharyanti (2002: 5) menemukan bahwa auditor yang berpengalaman mempunyai pemahaman yang lebih baik. Mereka juga lebih mampu memberi penjelasan yang masuk akal atas kesalahan-kesalahan dalam laporan keuangan dan dapat mengelompokkan kesalahan berdasarkan pada tujuan audit dan struktur dari sistem akuntansi yang mendasari (Libby et. al., 1985) dalam Mayangsari (2003: 4). Sedangkan Harhinto (2004) menghasilkan temuan bahwa pengalaman auditor berhubungan positif dengan kualitas audit.

\section{B.6. Independensi}

Dalam melaksanakan pemeriksaan, akuntan publik memperoleh kepercayaan dari klien dan para pemakai laporan keuangan untuk membuktikan kewajaran laporan keuangan yang disusun dan disajikan oleh klien. Oleh karena itu dalam memberikan pendapat mengenai kewajaran laporan keuangan yang diperiksa harus bersikap independen terhadap kepentingan klien, para pemakai laporan keuangan, maupun terhadap kepentingan akuntan public itu sendiri.

E.B. Wilcox (1952) dalam Supriyono (1989) menyatakan bahwa independensi bertujuan untuk menambah kredibilitas laporan keuangan yang disajikan oleh manajemen. Jika akuntan tidak independen terhadap kliennya, maka opininya tidak akan memberikan tambahan apapun.

Arens dan Loebbecke (1997) mendefinisikan independensi dalam pengauditan sebagai "pengguna cara pandang yang tidak bias dalam pelaksanaan pengujian audit, evaluasi hasil pengujian tersebut, dapat pelaporan hasil temuan audit.

Selain itu, Arens dan Loebecke (1997) mengkategorikan independensi ke dalam dua aspek, yaitu independensi dalam kenyataan (independence in fact) dan idependensi dalam penampilan (independence in appearance). 


\section{B.7. Kualitas Audit}

De Angelo (1981) dalam Watkins et al. (2004) mendefinisikan kualitas audit sebagai kemungkinan bahwa auditor akan menemukan dan melaporkan pelanggaran dalam sistem akuntansi dengan pengetahuan dan keahlian auditor. Sedangkan pelaporan pelanggaran tergantung kepada dorongan auditor untuk mengungkapkan pelang-garan tersebut. Dorongan ini akan tergantung pada independensi yang dimiliki oleh auditor tersebut.

Dari pengertian tentang kualitas audit di atas bahwa auditor dituntut oleh pihak yang berkepentingan dengan perusahaan untuk memberikan pendapat tentang kewajaran pelaporan keuangan yang disajikan oleh manajemen perusahaan untuk dapat menjalankan kewajibannya ada tiga komponen yang harus dimiliki auditor yaitu kompetensi (keahlian), independensi, dan due professional care. Tetapi dalam menjalankan fungsinya, auditor sering mengalami konflik kepentingan dengan manajemen perusahaan.

\section{B.8. Tujuan Kualitas Audit}

Tujuan audit mutu adalah untuk mendapatkan data dan informasi faktual dan signifikan sebagai dasar pengambilan keputusan, pengendalian manajemen, perbaikan dan/atau perubahan. Temuan hasil audit selanjutnya dianalisis, dinilai kecukupan dan kesesuaiannya terhadap standar ISO 9001:2008. Hasil temuan auditor tersebut akan digunakan sebagai dasar pengambilan keputusan, pengendalian manajemen, perbaikan dan/atau perubahan. Secara rinci tujuan umum dari audit mutu yaitu (Susilo, 2004) :

1) Untuk memperoleh prioritas permasalahan yang tengah dihadapi organisasi;

2) Untuk merencanakan pengembangan usaha untuk memenuhi persyaratan suatu sistem manajemen yang digunakan sebagai acuan;

3) Untuk memenuhi persyaratan regulasi ataupun persyaratan kontrak dengan (misalnya) pelanggan;

4) Untuk mengevaluasi terhadap pemasok;

5) Untuk menemukan adanya potensi resiko kegiatan organisasi

\section{B.9. Kerangka Pikir dan Pengembangan Hipotesis}

Salah satu fungsi dari akuntan publik adalah menghasilkan informasi yang akurat dan dapat dipercaya untuk pengambilan keputusan. Hal ini sesuai dengan teori atribusi yang menyatakan bahwa seorang auditor yang professional adalah perlu memiliki kompetensi melalui pengetahuan dan pengalaman yang dimiliki oleh seorang auditor serta memiliki independensi auditor. Namun adanya konflik kepentingan antara pihak internal dan eksternal perusahaan,menuntut akuntan publik untuk menghasilkan laporan audit yangberkualitas yang dapat digunakan oleh pihak-pihak tersebut, hal inilah yang memunculkan pertanyaan tentang bagaimana kualitas audit yang dihasilkan oleh akuntan publik dalam mengaudit laporan keuangan klien.

Menurut Christian (2002) yang menyatakan bahwa kualitas audit ditentukan oleh 2 hal yaitu kompetensi dan independensi. Kedua hal tersebut berpengaruh langsung terhadap kualitas audit. Dari teori tersebut di atas, dapat disajikan kerangka pikir yang dapat digambarkan sebagai berikut:

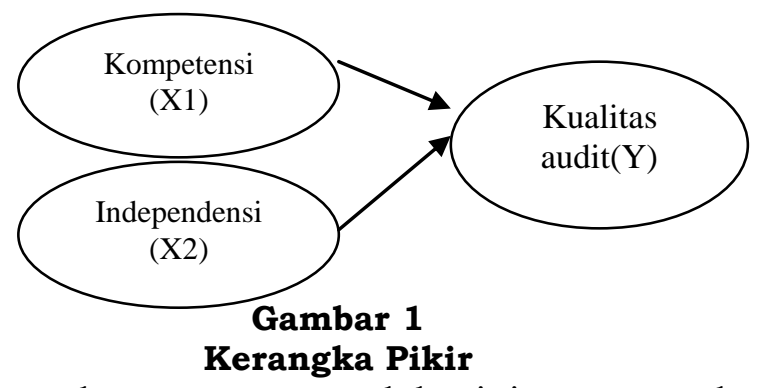

Dengan mengacu pada rumusan masalah, tinjauan pustaka serta kerangka pemikiran yang diuraikan sebelumnya, maka hipotesis yang diajukan dalam penelitian ini adalah:

B.9.1. Pengaruh Kompetensi Auditor terhadap Kualitas Audit. 
Kompetensi auditor adalah auditor yang dengan pengetahuan danpengalamannya yang cukup dan eksplisit dapat melakukan audit secaraobjektif, cermat dan seksama. Oleh karena itulah menurut Harhinto dalam penelitian Irawati (2011) yang menyatakan bahwa kompetensi auditor yang diukur dengan pengalaman berkorelasi positif dengan kualitas audit. Hal ini selaras dengan teori atribusi yang digunakan dimana apabila seseorang berperilaku tertentu, sedangkan orang lain tidak berbuat demikian, maka dapat dikatakan bahwa consensus orang tersebut rendah, begitu pula sebaliknya, sehingga orang tersebut mempunyai konsistensi yang tinggi (Sears et al., 1988) maka penulis memberikan hipotesis sebagai berikut:

$\mathrm{H}_{1}$ : Ada pengaruh kompetensi auditor terhadap kualitas audit.

B.9.2. Pengaruh Independensi Auditor terhadap Kualitas Audit

Independensi merupakan sikap yang diharapkan dari seorangakuntan publik untuk tidak mempunyai kepentingan pribadi dalammelaksana-kan tugasnya, yang bertentangan dengan prinsip integritas dan objektivitas, oleh karena itu cukuplah beralasan bahwa untuk menghasilkan audit yang berkualitas diperlukan sikap independen dari auditor. Oleh karena itulah menurut Irawati (2011) yang meneliti independensi auditor berpengaruh terhadap kualitas audit. Hal ini sejalan dengan penelitian yang dilakukan oleh Christiawan (2002) bahwa dalam melaksanakan pemeriksaan, akuntan publik memperoleh kepercayaan dari klien dan para pemakai laporan keuangan untuk membuktikan kewajaran laporan keuangan yang disusun dan disajikan oleh klien, oleh karena itu dalam memberikan pendapat mengenai kewajaran laporan keuangan yang diperiksa harus bersikap independen terhadap kepentingan klien, para pemakai laporan keuangan, maupun terhadap kepentingan akuntan publik itu sendiri, sehingga hipotesis atau jawaban sementara yang diajukan adalah:

$\mathrm{H}_{2}$ : Ada pengaruh independensi auditor terhadap kualitas audit.

\section{METODE PENELITIAN}

\section{C.1. Pendekatan Penelitian}

Penelitian ini termasuk penelitian deskriptif korelasional, yaitu berusaha mengungkap hubungan korelatif atau sebab dan akibat (causal) antara pengaruh variabel dependen dan independen dengan menggunakan analisa regresi linear berganda yang dinyatakan dalam suatu hubungan matematis yakni mengenai mengenai pengaruh kompetensi dan independensi terhadap kualitas audit pada Kantor Akuntan Publik yang ada di kota Makassar.

\section{C.2. Teknik Pengumpulan Data}

Teknik pengumpulan data yang digunakan dalam penelitian ini adalah kuesioner (daftar pertanyaan) yang diberikan kepada responden. Metode ini digunakan untuk memperoleh data primer. Kuesioner yang telah diisi dikembalikan dan selanjutnya diolah dengan menggunakan program SPSS.

\section{C.3. Populasi dan Sampel}

Populasi dalam penelitian ini yaitu Kantor Akuntan Publik di Makassar, yang dapat meliputi staf auditor baik itu partner, senior, dan yunior auditor pada Kantor Akuntan Publik.

Tabel 1

Jumlah Populasi

\begin{tabular}{|l|c|}
\hline \multicolumn{1}{|c|}{ Nama KAP } & Jumlah Auditor \\
\hline KAP. Rusman Thoeng & 8 \\
\hline KAP. Harley Weku & 7 \\
\hline $\begin{array}{l}\text { KAP. Blasius } \\
\text { Mangande }\end{array}$ & 7 \\
\hline KAP. Daniel Hassa & 7 \\
\hline KAP. Yakub Ratan & 5 \\
\hline KAP. Mansyur Sain & 8 \\
\hline $\begin{array}{l}\text { KAP. Usman dan } \\
\text { rekan-rekan }\end{array}$ & 8 \\
\hline
\end{tabular}




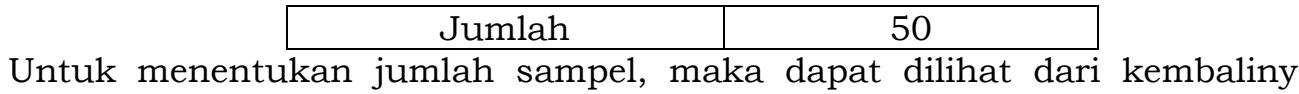 kuesioner, dan sampel yang kembali dianggap mewakili populasi, dengan teknik penarikan sampel yaitu purposive sampeling dengan kriteria yaitu: \\ a. Responden dalam penelitian ini yaitu auditor pada KAP di Makassar. \\ b. Responden yang dijadikan sampel penelitian telah bekerja diatas 2 tahun. \\ C.4. Metode Analisis}

Metode yang dipilih untuk analisis data harus sesuai dengan pola penelitian dan variabel yang akan diteliti. Adapun metode analisis yang digunakan adalah Analisis kuantitatif dengan menggunakan alat analisis regresi berganda yaitu suatu analisis yang digunakan untuk mengetahui pengaruh kompetensi dan independensi terhadap kualitas audit dengan menggunakan bantuan program SPSS release 24. Analisis data yang digunakan adalah analisis statistik deskriptif, uji kelayakan model dan uji hipotesis.

\section{ANALISIS DAN PEMBAHASAN \\ D.1. Statistik Deskriptif}

Sampel dalam penelitian ini adalah berjumlah sebanyak 50 orang auditor yang terdiri dari 7 Kantor Akuntan Publik di Makassar yang dapat menjadi staf auditor baik itu partner, senior dan junior. Untuk mendeskripsikan dan menggambarkan variabel dalam penelitian ini dapat dilihat pada tabel. Statistik deskriptif ini akan menghasilkan rata-rata dan deviasi standar. Sehingga secara kontekstual penelitian ini lebih mudah dimengerti oleh peneliti maupun penelitian yang akan datang. Untuk lebih jelasnya akan disajikan tabel statistik deskriptif yang dapat dilihat melalui tabel 2 .

Tabel 2

Statistik Deskriptif

\begin{tabular}{|l|r|r|r|r|}
\hline & $\begin{array}{c}\text { Kisaran } \\
\text { Teoritis }\end{array}$ & $\begin{array}{c}\text { Kisaran } \\
\text { Actual }\end{array}$ & Mean & $\begin{array}{c}\text { Std. } \\
\text { Deviation }\end{array}$ \\
\hline $\begin{array}{l}\text { Kompe } \\
\text {-tensi } \\
\text { Audito } \\
\text { r }\end{array}$ & $3-15$ & $7-13$ & 10.46 & 1.97 \\
\hline $\begin{array}{l}\text { Indepe } \\
\text { ndensi } \\
\text { auditor }\end{array}$ & $15-75$ & $35-60$ & 43.34 & 7.15 \\
\hline $\begin{array}{l}\text { Kualita } \\
\text { s Audit }\end{array}$ & $6-30$ & $18-29$ & 24.04 & 3.20 \\
\hline
\end{tabular}

Sumber: Output SPSS

Berdasarkan tabel statistik deskriptif mengenai penelitian kompetensi auditor yang memiliki kisaran teoritis 3-15, sedangkan kisaran aktual 7-19 dengan rata-rata score 10,46. Hal ini menunjukkan bahwa jumlah jawaban responden dari setiap pertanyaan lebih banyak responden memberikan jawaban setuju dari setiap item pertanyaan dalam kuesioner, hal ini berarti bahwa sebagian besar responden setuju bahwa untuk meningkatkan kualitas audit maka perlunya kompetensi auditor melalui pengetahuan dan pengalaman.

Selanjutnya dilihat dari variabel independensi auditor yang memiliki 15 item pertanyaan, di mana kisaran teori 35-60, sedangkan kisaran aktual 35-60 dengan rata-rata score 43,34. Hal ini menyatakan bahwa responden memberikan jawaban setuju dari setiap item pertanyaan dalam kuesioner. Hal ini berarti bahwa sebagian besar responden setuju bahwa untuk meningkatkan kualitas audit maka perlunya inde-pendensi auditor melalui lama hubungan, tekanan dari klien, telaah dari rekan auditor dan adanya jasa non audit. Kemudian dilihat dari kualitas audit dengan 6 item pertanyaan yang memiliki kisaran teori 6-30 dan kisaran actual 18-29 dengan rata-rata score 24,04. Dari skor tersebut di atas, bahwa responden memberikan jawaban setuju dari setiap item pertanyaan dalam kuesioner. 


\section{D.2. Uji Kualitas Data}

D.2.1. Pengujian Validitas

Analisis data diawali dengan menggunakan uji validitas. Validitas suatualat ukur adalah menunjukkan kesesuaian dari alat ukur tersebut yaitu item-item pertanyaan dalam kuesioner, dengan apa yang ingin diukur. Oleh karena itu, semua item pertanyaan yang digunakan dalam penelitian ini didasarkan pada item pertanyaan yang telah digunakan, maka korelasi yang digunakan adalah correlasion bivariate pearson dengan menggunakan program SPSS 24 melalui tabel berikut ini.

\section{Tabel 3}

Hasil Uji Validitas dengan alat Analisis Correlation Bivariate

\begin{tabular}{|c|c|c|c|c|}
\hline No & Variabel & $\begin{array}{c}\text { Jumlah } \\
\text { Item }\end{array}$ & $\begin{array}{c}\text { Jumlah } \\
\text { Item yang } \\
\text { diambil } \\
\end{array}$ & $\begin{array}{c}\text { Correla- } \\
\text { tion } \\
\text { Bivariate }\end{array}$ \\
\hline 1 & $\begin{array}{l}\text { Kompeten } \\
\text { si auditor }\end{array}$ & 3 & 3 & $\begin{array}{r}0,785- \\
0,876\end{array}$ \\
\hline 2 & $\begin{array}{l}\text { Independe } \\
\text { nsi auditor }\end{array}$ & 15 & 15 & $\begin{array}{c}0,426- \\
0,827\end{array}$ \\
\hline 3. & $\begin{array}{l}\text { Kualitas } \\
\text { audit }\end{array}$ & 6 & 6 & $\begin{array}{c}0,464- \\
0,847\end{array}$ \\
\hline $\begin{array}{c}\text { Total } \\
\text { pertanyaan }\end{array}$ & 24 & 24 & & \\
\hline
\end{tabular}

Sumber: Output SPSS

Berdasarkan tabel 3 yakni hasil uji validitas dengan menggunakan correlation bivariate maka dari 24 item pertanyaan yang diuji, ternyata semua item pertanyaan sudah valid, alasannya karena memiliki kisaran korelasi di atas dari 0,30 . Berarti dapatlah disimpulkan bahwa dalam penelitian ini memiliki itemitem tingkat keabsahan yang tinggi yang akan digunakan dalam pengolahan data uji hipotesis.

\section{D.2.2. Pengujian Reliabilitas}

Reliabilitas menunjukkan sesuatu instrumen yang dapat dipercaya dan digunakan sebagai alat pengumpul data karena instrumen dapat dipercaya dan reliabel yang akan menghasilkan data yang dapat dipercaya. Suatu data instrumen penelitian dikatakan reliabel apabila memiliki nilai cronbach's alpha di atas 0,60. Adapun hasil uji mengenai reliabilitas atas instrumen penelitian.

\section{Tabel 4}

Hasil Uji Reliabilitas Instrumen Penelitian

\begin{tabular}{|l|c|c|c|}
\hline \multicolumn{1}{|c|}{ Variabel } & $\begin{array}{c}\text { Jumlah } \\
\text { Item } \\
\text { Pertanya } \\
\text { an }\end{array}$ & Cronbach's alpha & $\mathrm{r}_{\text {standar }}$ \\
\hline $\begin{array}{l}\text { Kompetensi } \\
\text { auditor }\end{array}$ & 3 & 0,785 & 0,60 \\
$\begin{array}{l}\text { Independensi } \\
\text { auditor }\end{array}$ & 15 & 0,885 & 0,60 \\
Kualitas audit & 6 & 0,806 & 0,60 \\
\hline
\end{tabular}

Sumber: Output SPSS

Berdasarkan hasil olahan data uji reliabilitas dengan 24 item pernyataan, yang terdiri dari kompetensi auditor, independensi auditor dan kualitas audit, dimana untuk kompetensi auditor dengan nilai cronbach's alpha 0,785, kemudian untuk variabel independensi auditor dengan nilai cronbach's alpha sebesar 0,885 dan untuk variabel kualitas audit dengan nilai cronbach's alpha sebesar 0,806. Hal ini dapat disimpulkan bahwa semua item pertanyaan memiliki tingkat keandalan yang digunakan dalam penelitian ini.

\section{D.3. Analisis Regresi Linear Berganda}

Untuk menguji pengaruh kompe-tensi auditor dan independensi auditor terhadap kualitas audit digunakan persamaan regresi berganda yang bertujuan untuk mengetahui arah hubungan antara variabel independen dengan variabel 
dependen apakah positif atau negatif dan untuk memprediksi nilai dari variabel dependen apabila nilai variabel independen mengalami kenai-kan atau penurunan, dengan meng-gunakan persamaan regresi sebagai berikut:

$$
\mathrm{Y}=\mathrm{b}_{0}+\mathrm{b}_{1} \mathrm{X}_{1}+\mathrm{b}_{2} \mathrm{X}_{2}+\mathrm{e}
$$

Dari hasil persamaan regresi di atas, maka untuk lebih jelasnya akan disajikan hasil persamaan regresi atas kompetensi auditor dan independensi auditor terhadap kualitas audit yang dapat dilihat melalui tabel berikut ini :

\section{Tabel 5}

\section{Hasil Olahan Data Persamaan Regresi atas Kompetensi dan Independensi terhadap Kualitas Audit}

\begin{tabular}{|l|r|c|c|r|l|}
\hline Model & \multicolumn{2}{|c|}{$\begin{array}{c}\text { Unstandar } \\
\text { dized } \\
\text { Coefficients }\end{array}$} & $\begin{array}{c}\text { Standardized } \\
\text { Coefficients }\end{array}$ & T & \multirow{2}{*}{ Sig. } \\
\cline { 2 - 5 } & $\begin{array}{c}\text { B } \\
\text { Error }\end{array}$ & Beta & & \\
\hline (Constant) & $\begin{array}{r}7.21 \\
1\end{array}$ & 3.165 & & 2.27 & .027 \\
\hline Kompetensi Auditor & .390 & .184 & .240 & $\begin{array}{r}2.11 \\
5\end{array}$ & .040 \\
\hline Independensi Auditor & .258 & .051 & .578 & $\begin{array}{r}5.09 \\
1\end{array}$ & .000 \\
\hline
\end{tabular}

Sumber: Output SPSS

Berdasarkan tabel tersebut di atas yakni hasil olahan data SPSS versi 24 maka dapat disajikan persamaan regresi berganda yaitu sebagai berikut :

$$
\mathrm{Y}=7,211+0,390 \mathrm{X}_{1}+0,258 \mathrm{X}_{2}
$$

Berikut ini akan disajikan penjelasan dari persamaan regresi berganda yang dapat diuraikan sebagai berikut.

1. Koefisien konstanta $\left(b_{0}\right)$ sebesar 7,211 yang artinya tanpa adanya kompetensi dan independensi maka kualitas audit sebesar 7,211\%.

2. Kompetensi auditor $\left(b_{1}\right)$ sebesar 0,390 yang diartikan bahwa kompetensi auditor berpengaruh positif terhadap kualitas audit yang artinya semakin tinggi kompetensi auditor maka akan dapat meningkatkan kualitas audit.

3. Independensi auditor $\left(b_{2}\right)$ sebesar 0,258 yang artinya setiap kenaikan independensi auditor dapat diikuti oleh kenaikan kualitas audit. Dengan demikian dapatlah dikatakan bahwa independensi auditor berpengaruh positif terhadap kualitas audit pada Kantor Akuntan Publik di kota Makassar.

Dalam hubungannya dengan persamaan koefisien regresi yang sebagaimana telah diuraikan di atas maka dapatlah disimpulkan bahwa kompetensi auditor merupakan variabel yang dominan berpengaruh terhadap kualitas audit pada Kantor Akuntan Publik di kota Makassar.

D.3.1. Koefisien Determinasi

Kemudian diperoleh nilai $\mathrm{R}=0,628$ menunjukkan bahwa dengan nilai korelasi (R) sebesar 62,8\% menunjukkan bahwa kompetensi dan independensi auditor mempunyai hubungan yang kuat dan positif terhadap kualitas audit.Sedangkan nilai $\mathrm{R}^{2}$ (determinan) (Adjusted $R$ square) $=0,369$ atau 36,9\%, menunjukkan bahwa variasi dari kualitas audit dapat dijelaskan oleh variasidari kompetensi auditor dan independensi auditor, sedangkan sisanya sebesar 63,10\% dijelaskan oleh sebab-sebab lain yang tidak diteliti, hal ini dapat disajikan melalui tabel berikut ini.

Tabel 6

Model Summary

\begin{tabular}{|c|r|r|r|}
\hline $\mathrm{R}$ & $\begin{array}{c}\mathrm{R} \\
\text { Square }\end{array}$ & $\begin{array}{c}\text { Adjusted } \\
\text { R Square }\end{array}$ & $\begin{array}{c}\text { Std. Error of } \\
\text { the Estimate }\end{array}$ \\
\hline $.628^{\mathrm{a}}$ & .394 & .369 & 2,542 \\
\hline
\end{tabular}

Sumber: Output SPSS

D.3.2. Pengujian Hipotesis 
Pengujian hipotesis dapat dilaku-kan dengan 2 cara yakni pengujian secara serempak (uji F) dan pengujian secara parsial (uji t). Untuk melakukan pengujian secara serempak atau bersama-sama antara kompetens dan independensi terhadap kualitas audit maka dapat dilakukan dengan membandingkan antara nilai sig. dengan nilai standar $(0,05)$. Apabila nilai sig lebih kecil dari nilai standar berarti memberikan pengaruh secara serempak. Begitu pula sebaliknya apabila nilai sig, lebih besar dari nilai standar berarti tidak memberikan pengaruh secara serempak. Hasil pengujian secara serempak dapat disajikan pada tabel berikut ini.

Tabel 7

Uji Serempak (Uji F)

\begin{tabular}{|l|r|r|r|r|r|}
\hline Model & Sum of Squares & df & $\begin{array}{r}\text { Mean } \\
\text { Square }\end{array}$ & F & Sig. \\
\hline Regression & 197.993 & 2 & 98.996 & $\begin{array}{r}15.30 \\
9\end{array}$ & $\begin{array}{r}.00 \\
0^{\mathrm{b}}\end{array}$ \\
\hline Residual & 303.927 & 47 & 6.467 & & \\
\hline Total & 501.920 & 49 & & & \\
\hline
\end{tabular}

a. Dependent Variable : Kualitas audit

b. Predictors: (Constant), Independen Auditor, Kompetensi Auditor

Berdasarkan tabel hasil uji serempak maka diperoleh nilai $F_{\text {hitung }}$ sebesar 15,309 dengan menggunakan keyakinan 95\% dan tingkat signifikan 0,05 df = $47(n-k-1)$ atau $(50-2-1)=47$, maka diperoleh $F_{\text {tabel }}$ sebesar 3,195 (lihat lampiran). Karena nilai $F_{\text {hitung }}(15,309)>F_{\text {tabel }}(3,195)$ maka Ho ditolak artinya kompetensi dan independensi secara bersama-sama berpengaruh terhadap kualitas audit pada Kantor Akuntan Publik di Makassar.

Kemudian uji $t$ dimaksudkan untuk menge-tahui pengaruh secara signifikan masing-masing variabel yakni kompetensi dan independensi terhadap kualitas audit yang dapat dilihat melalui tabel 5, maka hasil pengujian hipotesis sebagai berikut.

1. Pengaruh kompetensi auditor terhadap kualitas audit

Pengaruh antara kompetensi auditor terhadap kualitas audit yang memiliki nilai koefisien regresi sebesar 0,390 dengan nilai sig sebesar 0,040. Hal ini menunjukkan bahwa ada pengaruh yang positif antara kompetensi auditor terhadap kualitas audit, sedangkan dilihat dari nilai sig 0,040 $<0,05$, berarti ada pengaruh yang signifikan antara kompetensi auditor terhadap kualitas audit, dengan demikian hipotesis yang telah dikemukakan sebelumnya terbukti. 2. Pengaruh independensi auditor terhadap kualitas audit

Pengaruh antara independensi auditor terhadap kualitas audit diperoleh koefisien regresi sebesar 0,258 dengan nilai sig sebesar 0,000. Hal ini dapat diartikan bahwa independensi auditor dengan kualitas audit berpengaruh positif. Sedangkan dengan nilai sig $0,000<0,05$, berarti independensi auditor ber-pengaruh positif dan signifikan. Dengan demikian maka penelitian ini sejalan dengan hipotesis yang telah dikemukakan sebelumnya.

\section{D.4. Pembahasan Hasil Penelitian}

Pembahasan dalam penelitian ini ditekankan pada pengujian pengaruh kompetensi auditor, independensi auditor terhadap kualitas audit, dimana sampel penelitian ini ditentukan sebesar 50 sampel. Adapun hasil pembahasan dapat diuraikan sebagai berikut.

D.4.1. Pengaruh Kompetensi Auditor terhadap Kualitas audit

Pengaruh kompetensi auditor terhadap kualitas audit dapat dikatakan berpengaruh positif dan signifikan, yang artinya semakin tinggi kompetensi auditor maka akan dapat memberikan dampak dalam meningkatkan kualitas audit. Kemudian dalam teori atribusi dan standar umum (SA Seksi 210 dengan SPA tahun 2001) yang mengemukakan bahwa audit harus dilakukan oleh seseorang atau lebih memiliki keahlian dan pelatihan yang cukup sebagai auditor. Sedangkan standar umum ketiga (SA Seksi 230 dalam SPAP 2001) menyebutkan bahwa dalam pelaksanaan audit dengan menyusun laporan audit menggunakan kemahiran profesiona-lisme dengan cermat. 
Teguh Harhito (2004) yang mene-liti pengaruh keahlian dengan independensi terhadap kualitas audit (studi empiris pada KAP di Jatim). Hasil penelitian menunjukkan keahlian dan independensi berpengaruh signifikan terhadap kualitas audit. Lebih lanjut E Farm, Beum (2007) yang meneliti pengaruh kompetensi dan independensi auditor terhadap kualitas audit. Hasil penelitian menemukan bahwa kompe-tensi auditor berpengaruh terhadap kualitas audit baik secara parsial dan simultan. Sedangkan Sitti (2011) yang meneliti pengaruh kompetensi dan independensi auditor secara parsial berpengaruh terhadap kualitas audit.

Kemudian hasil penelitian yang dilakukan, menunjukkan ada pengaruh yang signifikan antara kompetensi auditor dengan kualitas audit. Dengan demikian dapatlah dikatakan bahwa penelitian yang dilakukan oleh peneliti yang menunjukkan bahwa dalam penelitian ini mendukung hasil penelitian yang dilakukan oleh Teguh dan Efarm. Sehingga dapatlah disimpul-kan bahwa dalam melakukan pemberian pelayanan jasa audit kepada kliennya maka setiap auditor harus memiliki kompetensi di bidang jasa audit, agar kualitas audit yang dihasilkan dapat memberikan kepuasan bagi kliennya. Faktor-faktor yang mempengaruhi antara kompetensi auditor dengan kualitas audit didukung oleh faktor pendidikan dan pelatihan. Hal ini dapat dilihat dari setiap akuntan publik telah memahami dan melakukan jasa profesionalnya sesuai dengan SAK dan SPA, dan disamping itu dalam melakukan audit, auditor rata-rata telah memahami kondisi perusahaan klien. Faktor lainnya bahwa auditor membutuhkan pendidikan formal dalam pelaksanaan audit. Pendidikan formal yang dibutuhkan diperoleh dari pelatihan di bidang audit yang tujuannya untuk mendukung proses audit yang akan dilakukan.

Kemudian dilihat dari jawaban responden mengenai pengalaman yang menunjukkan bahwa dengan banyaknya pengalaman yang dimiliki maka menjadikan audit yang dilakukan akan semakin baik dan selain itu dengan adanya kenaikan jumlah klien yang ditangani, maka akan memberikan pengalaman dalam bidang audit sehingga dapat menghasilkan kualitas audit yang dapat dipercaya.

D.4.2. Pengaruh Independensi Auditor terhadap Kualitas Audit

Pengaruh independensi auditor terhadap kualitas audit setelah dilakukan uji regresi menemukan ada pengaruh yang positif dan signifikan. Hal ini dapat diartikan bahwa setiap kenaikan independensi auditor maka dapat meningkatkan kualitas audit. Hal ini dipengaruhi oleh faktor lainnya seperti lama hubungan klien, tekanan dari klien, telaah rekan auditor serta jasa non audit.

Hasil penelitian yang dilakukan oleh Sitti (2011) menemukan ada pengaruh yang positif dan signifikan antara independensi auditor dengan kualitas audit. Kemudian teori atribusi lainnya yakni Harhinto (2004) yang menemukan bahwa antara independensi auditor dengan kualitas audit berpengaruh secara signifikan terhadap kualitas audit. Sedangkan dari penelitian yang dilakukan oleh peneliti yang menunjukkan bahwa antara independensi dengan kualitas audit berpengaruh signifikan. Dengan demikian hasil penelitian ini sejalan dengan teori atribusi yang dilakukan oleh Sitti dan Harhinto.

Kemudian dari hasil persepsi responden mengenai pertanyaan dalam kuesioner, dimana dilihat dari lamanya hubungan dengan klien rata-rata auditor memiliki hubungan klien paling lama 3 tahun, selanjutnya auditor tetap bersifat independensi walaupun menjalani hubungan dengan klien. Sehingga dari persepsi responden dilihat tekanan dari klien yang menunjukkan bahwa setiap auditor dalam melakukan audit rata-rata tidak melakukan kesalahan klien sebab akan mendapat peringatan dari klien.

Selanjutnya dilihat dari persepsi responden mengenai telaah dari rekan auditor rata-rata menunjukkan bahwa auditor senantiasa bersifat jujur guna menghindari penilaian kurang dari rekan seprofesi. Sedangkan dilihat dari persepsi responden mengenai jasa non audit maka Kantor akuntan rata-rata memberikan jasa-jasa lainnya kepada klien yang sama, jasa non audit yang diberikan seperti : jasa mengenai perusahaan yang akan diaudit. 


\section{E. PENUTUP}

Berdasarkan hasil pengujian hipotesis, diperoleh kesimpulan penelitian bahwa kompetensi Auditor berpengaruh secara positif dan signifikan terhadap kualitas audit pada kantor Akuntan Publik di kota Makassar. Hal ini dapat dikatakan bahwa kompetensi auditor dapat memberikan pengaruh yang berarti dalam meningkatkan kualitas audit pada KAP di kota Makassar. Independensi Auditor berpengaruh secara signifikan terhadap kualitas audit pada Kantor Akuntan Publik di kota Makassar.Hal ini dapat dikatakan bahwa independensi memberikan pengaruh yang berarti dalam meningkatkan kualitas audit pada KAP di kota Makassar.

Berdasarkan hasil penelitian yang telah dilakukan, kompetensi dan independensi auditor berpengaruh secara signifikan terhadap kualitas audit. Hal ini menunjukkan bahwa dengan adanya pengetahuan dan pengalaman yang dimiliki oleh seorang auditor maka dapat meningkatkan kualitas audit. Begitu pula dengan adanya independensi auditor melalui lama hubungan, tekanan dari klien, telaah dari rekan auditor serta jasa non audit merupakan faktor yang dapat mempengaruhi kualitas audit. Berarti seorang auditor yang profesional perlu memiliki kompetensi dan independensi auditor untuk meningkatkan kualitas audit.

Secara teoritis penelitian ini memberikan bukti bahwa penelitian dengan konteks kualitas audit dan menggunakan subyek auditor mem-punyai karakteristik yang khas yang berbeda dengan konteks sederhana. Dan juga penelitian ini diharapkan dapat memberikan kontribusi atau masukan pengetahuan dalam pening-katan kualitas auditor.

Hasil penelitian ini diharapkan dapat menjadi masukan bagi Kantor Akuntan Publik yang ada di kota Makassar untuk dapat meningkatkan kualitas audit yang vsesuai dengan SA dan SAP. Selain itu, hasil penelitian ini diharapkan dapat mempertegas hasil penelitian yang dilakukan oleh Irawati (2011), bahwa dengan adanya pengetahuan dan pengalaman yang dimiliki seorang auditor serta adanya independensi auditor maka dapat meningkatkan kualitas audit. Dengan demikian hasil penelitian ini diharapkan dapat menjadi referensi bagi penelitian berikutnya.

Penelitian ini terbatas pada objek penelitian profesi auditor yang bekerja dalam Kantor Akuntan Publik (KAP) di Makassar. Sehingga dimungkinkan adanya perbedaan hasil, pembahasan ataupun kesimpulan untuk obyek penelitian yang berbeda. Pengukuran kualitas audit akan lebih baik jika menambahkan obyek penelitian lain misalnya pimpinan Kantor Akuntan Publik (KAP).

Saran-saran yang dapat diberikan sehubungan dengan hasil penelitian yang dilakukan adalah sebagai berikut:

1. Menjadi masukan bagi akuntan publik dalam meningkatkan kualitas audit bagi setiap auditor yang melayani jasa pemeriksaan laporan keuangan bagi setiap pemakai jasa audit.

2. Menjadi masukan atau referensi bagi pihak yang melakukan penelitian selanjutnya, khususnya yang membahas tentang kompetensi auditor dan independensi auditor terhadap kualitas audit.

3. Sebaiknya untuk peneliti selanjutnya hendaknya menambah variabelvariabel yang kiranya dapat meningkatkan kualitas audit, diluar dari pada variabel yang peneliti teliti, misalnya melalui : gender, umur, tingkat pendidikan responden dan sebagainya.

\section{DAFTAR PUSTAKA}

Abdulmohammadi, Mohammad dan Arnold Wright. (1987). "An Evamination of the effectof Experince and Task Comlexity on Audit Judgement". The Accounting Review (January)-Pp 1-3 
Amirin, Tatang. 2009. Populasi dan Sampel Penelitian 3: Pengambilan Sampel dari Populasi Tak Terhingga dan Tak Jelas.

Arikunto, Suharsimi. 2002. Prosedur Penelitian: Suatu Pendekatan Praktek. Edisi Revisi IV, Jakarta: Rineka Cipta.

Ashton, Alison Hubbard. (1991). "Experience and Error Frequency Knowledge as Potential Determinants of Audit Expertise." The Accounting Review (April), pp. 218-239

Baron, Robert, A, dan Byrne Donn. (1991). Social Psychology. Under-standing Human Interaction, Sixth edition, Boston, Alyn and Bacon inc.

Boynton, William C., dan Jhonson Raymond, Walter G. Kell. 2003. Modern Auditing. Edisi Ketujuh. Erlangga: Jakarta.

Bonner, Sarah E. (1990). "Experience Effects in Auditing: The Role Task Spesific knowledge". The Accounting Review (Januari), pp. 72-92

Choo, Freddie, dan Ken T. Trotman. (1991). "The Relationship Between Knowledge Structure and Judgements for Experienced and Inexperienced Auditors". The Accounting Review (Juli), pp. 464-485.

Christiawan, Yulius Jogi. (2002). "Kompetensi dan Independensi Akuntan Publik. Refleksi Hasil Penelitian Empiris". Jurnal Akuntansi dan Keuangan Vol. 4 No. 2 (Nov) Hal. 79-92

Deis, Donald L. dan Gari A. Giroux. (1992). "Determinants of Audit Quality In The Public Sector". The Accounting Review Vol. 67 No. 3 (Juli). Pp. 462-479.

Elfarini, Eunike Christina. 2007. Pengaruh Kompetensi dan Independensi Auditor Terhadap Kualitas Audit (Studi Empiris pada Kantor Akuntan Publik di Jawa Tengah. Skripsi Fakultas Ekonomi Pada Universitas Negeri Semarang

Gujarati, D. (1999). "Ekonometrika". Jakarta: PT. Gelora Aksara Pratama.

Ghozali, Imam. (2005). "Aplikasi analisis multivariat dengan program SPSS". BP Undip

Hernadianto. (2002). "Pengaruh Pengalaman Auditor Terhadap Pengetahuan dan Penggunaan Intuisi Mengenai Kekeliruan (Pada KAP di Jateng dan DIY)". Semarang. Tesis Maksi di Universitas Diponegoro

Halim, Abdul. 2001. Auditing I (Dasar-Dasar Audit Laporan Keuangan. Edisi Kedua (Revisi). Yogyakarta: UPP AMP YKPN.

Harhinto, Teguh. (2004). "Pengaruh Keahlian dan Independensi Terhadap Kualitas Audit Studi Empiris Pada KAP di Jawa Timur". Semarang. Tesis Maksi di Universitas Diponegoro.

IAI. 2001. "Standar Profesi Akuntan Publik". Jakarta: Salemba Empat.

Indriantoro, Nur dan Bambang Supeno. 1999. Metode Penelitian Bisnis. Edisi I. Yogyakarta: BPFE 
Indah, Nur Mawar Siti. (2010). Pengaruh Kompetensi dan Independensi Auditor Terhadap Kualitas Audit (Studi Empiris Pada Auditor KAP di Semarang). Skripsi Fakultas Ekonomi Universitas Diponegoro Semarang

Irawati, Nur (2011). Pengaruh Kompe-tensi dan Independensi Auditor terhadap Kualitas Audit pada Kantor Akuntan Publik di Makassar. Jurnal Fakultas Ekonomi dan bisnis Universitas Hasanuddin

Khomsiyah dan Nur Indriantoro. (1998). "Pengaruh Orientasi Etika terhadap Komitmen dan sensitivitas etika auditor Pemerintahan di DKI Jakarta". Jurnal Riset Akuntansi Indonesia Vol.1 No.1.

King, James, Robert Welker dan Gary Keller. (1994). "The Effect of Independence Allegation on Peer Review Evaluation of Audit Procedures". Behavioral Research in Accounting Vol. 6

Knapp, Michael C. (1985). "Audit Conflict: an Empirical Study of the perceived Ability ofAuditor to Resists Management Pressure". The accounting Review (April), pp.202-211

Kusharyanti. (2003). "Temuan penelitian mengenai kualitas audit dan kemungkinan topic penelitian di masa datang". Jurnal Akuntansi dan Manajemen (Desember). Hal.25-60

Manani, Naim M. (2010). Pengaruh Kompetensi dan Independensi Terhadap Kualitas Audit dengan Etika Auditor Sebagai Variabel Moderasi (Studi Empiris Pada Kantor Akuntan Publik di Jawa Tengah). Skripsi Fakultas Ekonomi Jurusan Akuntansi Universitas Muhammadi-yah Surakarta

Masran, Jimmy. 2007. Pengaruh Kemampuan Kerja dan Motivasi terhadap Kinerja Karyawan. Jurnal Fakultas Ekonomi Universitas Hasanuddin

Mayangsari, Sekar. (2003). Pengaruh keahlian dan independensi terhadap pendapat audit: Sebuah kuasi-eksperimen. Jurnal Riset Akuntansi Indonesia Vol.6 No.1 (Januari)

Meutia, Intan. (2004). "Independensi auditor terhadap Manajemen Laba Untuk Kap Big 5dan non Big 5". Jurnal Riset Akuntansi Indonesia Vol. 2 No. 1 (Januari). Pp 37-52

Mulyadi. (2002). Auditing. Buku Satu. Edisi Keenam. Penerbit Salemba Empat: Jakarta

Mulyadi dan Kanaka Puradiredja. 1998. Auditing Pendekatan Terpadu. Jakarta. Salemba Empat.

Nurchasanah, Rizmah dan Wiwin Rahmanti. 2003. Analisis Faktor-Faktor Penentu Kualitas Audit. Akuntansi dan Manajemen (Agustus). Hal.47-60

Purnomo, Adi, 2007. Persepsi Auditor Tentang Pengaruh Faktor-Faktor Keahlian Dan Independensi Terhadap Kualitas Audit. Tersedia: http://www. library@lib. unair.ac.id

Santosa, Purbayu Budi dan Ashari. 2005. Analisis Statistik dengan Microsoft Excel dan SPSS. Andi: Yogyakarta.

Sulaiman, Wahid. Analisis Regresi Menggunakan SPSS. 2004. Andi: Yogyakarta 
Saifudin. (2004). Pengaruh Kompetensi dan Independensi Terhadap Opini Audit Going Concern (Studi Kuasieksperimen Pada Auditor Dan Mahasiswa). Tesis Program Pasca Sarjana Magister Akuntansi Universitas Diponegoro.

Sears, D. A., Freedman, J. L. Peplau, L. A,. 1988. Psikologi Sosial I. Edisi Kelima. Jakarta: Erlangga.

Supriyono, R. A. (1988). Pemeriksaan Akuntan (Auditing) Faktor-faktor yang Mempengaruhi Independensi Penampilan Akuntan Publik. Penerbit BPFE: Yogyakarta

Suyatmini. (2002). Sudi Empiris Faktor-Faktor Yang Mempengaruhi Independensi Akuntan Publik. Tesis Program Pasca Sarjana Magister Akuntansi Universitas Diponegoro.

Simamora, Henry. (2002). Auditing. Jilid Satu. Cetakan Pertama. Penerbit UPP AMP YKPN: Yogyakarta

Sunarto. (2003). Auditing. Edisi Pertama. Cetakan Pertama. Penerbit Pena Persada: Jakarta

Tsui, Judi S. L. dan Ferdinand A. Gul. (1996). "Auditors Behavior in an audit. Conflict Situation: A Research Note on the Role of Locus of Control and Ethical Reasoning". Acoounting Organization and Society Vol. 21, No. 1, pp.41-51.

Walgito, B, 2001. Pengantar Psikologi Umum. Yogyakarta: Andi

Watkins, Ann. L, William Hillison and Susan E. Morecroft. (2004). "Audit Quality: A Synthesis Of Theory And Empirical Evidence". Journal of Accoounting Literature Vol.23. Pp. 153-193

Widiastuti, Harjanti. 2002 . Peer Review: Upaya Meningkatkan Kualitas Jasa Firma Akuntan Publik. Akuntansi dan Investasi Vol. 3 (Januari) Hal. 5160 .

Winarto, Joko. (2011). Teori Atribusi Berner Weiner dan Implementasinya dalam Pembelajaran. Tersedia: http://edukasi.kompasiana.com/2011/03/12/teori-atribusi-bernerweiner-dan-implementasinya-dalam-pembelajaran/ 